\title{
朝鮮李朝における「営建都監」組織の変化について \\ ON THE CHANGES IN THE CONSTRUCTION WORK ORGANIZATION DURING THE YI-DYNASTY OF KOREA
}

\author{
中西章* \\ NAKANISHI Akira
}

\begin{abstract}
This paper is about the changes in construction work organization, "Do-Gam", during the Yi-Dynasty of Korea. The findings are as follows.

At the ealy stage of the dynasty, the organization of construction work took over that ofKoryo-Dynasty . It underwent some changes during the 15th and 16th century. Toward the second half of the dynasty it was greatly enlarged, mainly composed of bureaucats from the central government. But its scale was reduced after the middle of the 18th century.
\end{abstract}

key words : Korea, Yi-Dynasty, construction work

朝鮮、李朝、営建都監、営建組織

\section{1. 序}

朝鮮、李朝においては、大規模な建築工事に際して通常の工事組 織とは別に「営建都監」（以下、「都監」とする）という臨時組織 が作られ工事を遂行した。この「都監」による工事は李朝における 官営の建築工事の中心であり、李朝の建築工事の状況を知る上で重 要なものである。本稿は、この「都監」の構成および構成員につい て考察し、その李朝を通じての変化をあきらかにしようとするもの である。

李朝における建築活動については、杉山信三博士による高麗末か ら李朝初期の各王による造営活動とその監董者についての研究があ $ろ^{11}$ 。また、李朝における建築工事の組織については、李朝前期で はソウル南大門（1448）、後期では華城（水原城：1796）の工事記 録を通じて、申栄勲氏と金東旭博士がそれそれに概要を示している 2)。そして、金東加博土は李朝における官営工事の記録である「営 建都監儀軌」の記事を通じて李朝の官庁における建築工匠組織の変 遷を論じている ${ }^{3)}$ 。さらに、朴彦坤・李王基博士は李朝の営建職制 の研究のなかで、李朝前期を中心に監董者について触れており ${ }^{4)}$ 、 洪錫珠・朴彦坤博士は光海君代の宮闒造営について、「都監」の組 織や構成貝について考察している5゙。しかし、李朝を通じての「都
監」の工事組織の構成および構成員についての詳しい検討は残され た問題であると思われる。

\section{2. 李朝前期の「都監」}

李朝の「都監」について『增補文献備考』には 本朝有事則設都監有都監都提調提調都廳郎廳監造官随事增減其 規不一

とあり ${ }^{6) 、}$ 構成員として都提調、提調、都庁、郎庁、監造官がある とされる。しかし、『增補文献備考』は、英祖46年 (1770) に最初 に編算された『東国文献備考』がもとになっており 、これがその まま李朝の全時代を通じた「都監」の組織といえるものではない。 李朝前期の「都監」のうち、『李朝実録』の記事をもとに、組織 がある程度わかるおもなものを示したものが表 1 である。の表を みると、太祖が李朝を開いた直後の14世紀末には、「都監」は判事 を筆頭として組織されている。判事以下の組織は、太祖 4 年 (1395) の都城造築都監にみられるように、副判事・使・副使・判官・録事 で構成されていたとみられる。この工事では、城壁 600尺を「字」 として、一字をさらに六つの「号」に分けている。そして、そのニ 字ごとに判事・副判事を各 1 人置き、さらに使・副使・判官 12 人を 置いている

\footnotetext{
* 東京工業大学工学部附属工業高等学校 教諭·工博 Teacher, Technical High School Attached to Tokyo Institute of Technology, Dr. Eng.
} 
このような李朝最初期の「都監」の構成は、上記の『增補文献備 考』に記されている構成とは異なっており、このような構成は、高 麗の都監の制度を受け継いでいるものとみられる。高麗の建築関係 の都監の構成についてはあきらかではないか、『高麗史』にはさま さまな都監について構成が記録されており、「使、副使、判官」な どが主な構成員とされている ${ }^{92}$ 。また、裸王14年(1388)に公主が亡 くなった際に「設貿殿国葬造墓斎四都監各置判事使副使判官録事」 とあり、この都監が判事・使・副使・判官・録事で構成されている ことがわかる(0)。

このような組織は、15世紀に入ると、判事・副判事に代わって都 提調・提調がみられるようになる ${ }^{11)}$ 。判事、副判事と都提調、提 調の具体的な職責の違いは不明であるが、徐々に『増補文献備考』 の「都監」に近い構成に変わっているといえる。しかし、太宗16年 (1416)の都城修築都監や世宗 3 年 (1421)の都城修築都監でみられる ように、都提調・提調以下の組織は、李朝初期の太祖の時代と同じ く、使・副使・判官・録事で構成されている。世宗 3 年の工事では、 右議政鄭擢を都提調として、提調を 33 名、使・副使 ·判官 ·録事 2 90名を置いている ${ }^{12)}$ 。

さらに、15世紀後半から16世紀の都監では、成宗18年(1487)の春 宮都監や、燕山君10年(1504)の文廟都監では、提調の下に郎庁が漚 かれている。郎庁は『増補文献備考』に記された「都監」でみられ るものであり、「都監」の構成が李朝の構成に近いものとなってき ていることがわかる。また、「都監」とは明記されていないが、端 宗即位年 (1452)の昌德宮の重修工事に関連して、都庁という呼称が みえる。この都庁が『增補文献備考』の「都監」の都庁と直接結び つくかどうかはわからないが、この時、都庁に任じられた者は工匠 などの使役に大きな権限を持ち、実質的に工事の中心であった ${ }^{13) 。 ~}$

このほか、燕山君10年(1504)の文廟都監や明宗 9 年(1554)の造成 都監では堂上という呼称がみられる。堂上官は正三品以上の品階を

\section{表 1 李朝前期の「都監」}

\begin{tabular}{|c|c|c|c|}
\hline 年 & 代 & 都 監 名 & 織 \\
\hline & 祖 2(1393) & 京城修築 & 判事 \\
\hline & 祖 3 (1394) & 新都宮闒造成 & 判事 \\
\hline & 祖 4 (1395) & 都城造築 & $\begin{array}{r}\text { 判事·副判事 ·使 · 副使 · } \\
\text { 判官 · 録事 }\end{array}$ \\
\hline & 宗 4 (1404) & 漢京離宮造成 & 提調 \\
\hline & 宗11(1411) & 開渠 & 提調 \\
\hline & 宗13(1413) & 京城修補 & 都提調 - 提調 \\
\hline & 宗15(1415) & 行廊 & 提調 \\
\hline & 宗16(1416) & 都城修築 & 提調 - 使 · 副使 - 判官 \\
\hline & 宗 3 (1421) & 都城修築 & $\begin{array}{r}\text { 都提調 - 提調 - 使 · 副使 } \cdot \\
\text { 判官 - 録事 }\end{array}$ \\
\hline 世 & 祖 7 (1461) & 修理（景福宮） & 都提調・提調 \\
\hline & 宗15(1484) & 修理（昌慶宮） & $\begin{array}{l}\text { 都提調 - 提調 - 瓦署提調 } \\
\text { 郎庁・瓦署別提 - 録事 } \\
\text { /堂上 - 郎庁 }\end{array}$ \\
\hline & 宗18(1487) & 春宮 & 提調·郎庁·画員·医貝 \\
\hline 燕山 & 」君10(1504) & 文廟 & 提調・郎庁／堂上 \\
\hline 燕山 & 君11(1505) & 修理 & 提調 \\
\hline $\begin{array}{r}\text { 燕山 } \\
(1\end{array}$ & $\begin{array}{l}\text { J伊代 } \\
1494 \sim 1506)\end{array}$ & 修理・築城 & $\begin{array}{r}\text { 都提調・副提調 · 郎官 } \cdot \\
\text { 監役官 }\end{array}$ \\
\hline 明 & 宗 8 (1553) & 造成（東宮） & 都提調・提調 \\
\hline 明 & 宗 8 (1553) & 大内繥修 & 提謂 \\
\hline & 宗 9 (1554) & $\begin{array}{r}\text { 緗修（景福宮· } \\
\text { 東宮） }\end{array}$ & 堂上·郎庁 \\
\hline
\end{tabular}

持つ者の一般的な呼称で ${ }^{14)}$ 、この堂上は特に都監における組織の 名称ではなく、「都監」の構成員のうち正三品以上の者を指してい る語と考えられる。

\section{3.ソゥル南大門の工重組䋍}

李朝前期の建築工事組織をより詳しく考察するための資料にソウ ル南大門で修理工事の際に発見された墨書（上梁文）がある ${ }^{15) 。 ~}$ これらのエ事について「都監」を立てたとは明記されていないか、 都城の正門である南大門の創建・再建・修理工事であり、当然「都 監」あるいはそれに類する工事組織が作られたとみられる。そこで、 この圊書をもとに表 2 に各工事組織の構成と人数を記し、この表に 基づいてそれそれれエ事の構成についてみて行く。

\section{（1）浃武29年(1396)の工事と工事組繪}

このエ事は、李朝太祖による漢城（現ソウル）遷都にともなう都 城の創建工事の一環として行われたものである。墨書は、洪武29年 (1396)10月のもので、2 件発見されている。一つは上層の母屋桁に 添えた材（長舌）、今一つは棟木の上面から発見されている。

工事組織は、判事を筆頭 ${ }^{16)}$ に、副判事 2 名、使 3 名、副使 2 名、 そして 11 名の判官と別監役、掌務録事で構成されている。このよ うな判事を筆頭とした構成は、前述の李朝最初期の「都監」の組織 と同様であり、南大門の工事も遷都に伴う都城の造営の一環であり、 このような構成を踏襲しているとみられる。

判事以下の構成員の品階を後述する李朝後期の「都監」の組織と 比較してみると、判事・副判事が二品程度の品階を持っており李朝 後期の「都監」の提調、使と副使が三・四品程度で都庁、判官は五 品程度で郎庁に相当する。しかし、後述するように、李朝後期の 「都監」は都提調となる議政府の議政クラスの者を筆頭に六曹の現 瞕の官吏を中心に政府組織をそのまま移したような構成であったが、 ここでは前職の者がほとんどであり、使・副使に六曹の現職の官吏 はまったく含まれていない点に違いがある。

\section{（2）正統13年(1448)の工事と工事組維}

『世宗実録』に「新作崇礼門…」とある ${ }^{17)}$ 工事で、南大門の再 建ないしは大規模な改筑工事と考えられる。墨書は正統13年 (1448) 3 月のもので、上下 2 段ある棟木のうちの上の棟木の下面から発見 された。

この墨書にみられるエ事組織は、提調として「正憲大夫議政府左 参賛判戸曹事鄭苯」と「資雪大夫刑曹判書閥伸」の 2 名が記されて いる。続いて監役官として 6 名が記され、さらに欠字が多いが別監 役として 12 〜 名がみられる。

表 2 ソゥル南大門の建築工事組繶

\begin{tabular}{|c|c|c|}
\hline 洪武 29 年 (1396) & 正 統 13年 (1448) & 成化 15 年 (1479) \\
\hline 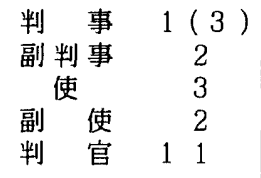 & 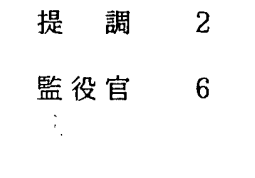 & $\begin{array}{lll}\text { 提 } & \text { 調 } & 8 \\
\text { 郎 } & \text { 庁 } & 5\end{array}$ \\
\hline 掌務録 事 & 別監役 $12 \sim 3$ & $\begin{array}{c}\text { 邻口部将 } \\
\text { 月令医貝 } \\
\text { 衙 前 }\end{array}$ \\
\hline
\end{tabular}


提調の品階が正二品であるため、都提調はみられないが、提調を 筆頭におく構成は、前述の15世紀後半以降の「都監」の構成と同じ である。しかし、李朝後期の「都監」のような都庁・郎庁はみられ ず、品階の上からみると監役官に正三品から従七品まで広い範囲の 者があてられ、都庁・郎庁・監役官（監造官）が未分化の形を示し ているとみることができる。すなわち、この正統13年の工事の組織 は、完全には『増補文献備考』の「都監」のような組織になってい るとはいえず、李朝最初期の「都監」のような高麗以来の構成から 変化する過渡的な構成といえる。なお、提調には賦役に関わる戸曹、 監役官には建築工事を掌る繥工監の者が含まれている点は、李朝後 期の「都監」と共通している。

\section{（3）成化15年(1479)の工事と工事組絴}

南大門の「傾頽」が著しいための改築工事である ${ }^{18)}$ 。圊書は成 化15年(1479) 4 月のもので、上層北側の母屋桁の下面から発見され ている。

この工事では、提調として「正憲大夫知中枢府事韓継純」をはじ め 8 名が記され、続いて郎庁が 5 名、そして邻口部将 2 名、月令医 貝 1 名、敔前 4 名がおり、大木などの工匠に続いて領役使令が記さ れている。

提調は二品から三品、このなかには賦役に関わる戸曹、土木・建 築工事を管掌する工曹の者が含まれている。後に述べるように、李 朝後期の「都監」でも提調に戸曹、工曹の判書などが含まれており、 李朝後期の「都監」に近い構成といえる。また、郎庁も緬工監の者 2 名と、工曹、戸曹、兵曹の正郎各 1 名で構成されている点も李朝 後期の「都監」に近い構成である。

このほか邻口部将は「領役部将」とみられ、医員・使令などとと もに李朝後期にもみられるものである。なお衙前は六曹の書吏が配 されており、李朝後期にみられる「員役」のように事務的な仕事を する者と考えられる。

\section{4. 李朝後期、18 世紀半ば以前の「都監」の樰成と棬成者}

李朝後期の「都監」については「都監」による工事記録である 「営建都監儀軌」（以下、「儀軌」とする）が残されており、より 詳しい構成がわかる。以下、表 3 にあげた李朝の「儀軌」20点を資 料として、李朝後期の「都監」の構成について考察する。

李朝後期の「儀軌」に記録された「都監」のうち、18世紀半ばま

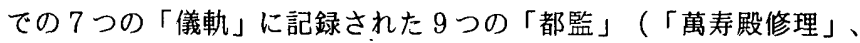

「永寧殿修改」では途中で一旦工事を中止しており、その前後で 2 つの「都監」が記録されている。）では、前述の『増補文献備考』 に示されているような「都監」の構成がみられる。これらの「都 監」の構成は表 4 に示したが、李朝後期の「都監」のうち、まずこ れらの「都監」における都提調以下の構成貝について検討する。

\section{（1）都提調・提調および堂上}

都提調・提調は 7 つの都監」でみられ、都提調は 1 人、提調は $3 \sim 5$ 人である。都提調・提調がみられない「昌慶宮修理」と「南 別殿重建」ではそれそれ 7 人、3人の堂上がいる。

都提調は交代を含めて延 8 人であるが、議政府領議政 4 、同左議 政 1、同右議政 2、領中枢府事 1である。品階はすべて正一品であ り、「都監」中のもっとも高位の者で工事の総責任者とみられる。 前記『増補文献備考』の冊禮都監には

[補] 冊禮都監都提調一貝 議政…

とあり ${ }^{19)}$ 、都提調は議政府の議政クラスの正一品の者が基本であ ったと考えられる。

表 3 盗料とした「営建都監儀軌」

\begin{tabular}{|c|c|c|}
\hline 軌 & 代 & 所 \\
\hline 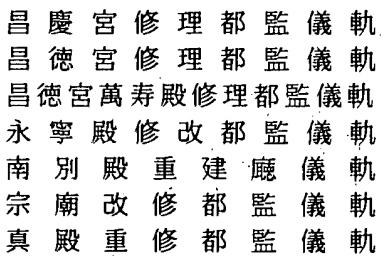 & $\begin{array}{ll}\text { 仁祖11 } & (1633) \\
\text { 二祖 25 } & (1647) \\
\text { 孝宗 8 } & (1657) \\
\text { 影宗 } 8 & (1667) \\
\text { 肃宗 3 } & (1677) \\
\text { 䔨正 3 } & (1725) \\
\text { 乾隆13 } & (1748)\end{array}$ & $\begin{array}{l}\text { 奎章閣 } \\
\text { 蔵書閣 } \\
\text { 蔵書閣 } \\
\text { 蔵書閣 } \\
\text { 奎章閣 } \\
\text { 奎章閣 } \\
\text { 蔵書閣 }\end{array}$ \\
\hline 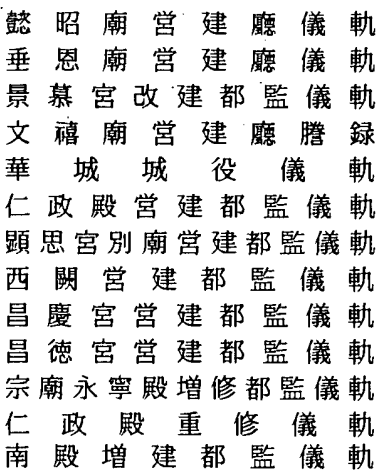 & $\begin{array}{l}\text { 乾隆 } 17(1752) \\
\text { 乾隆27 }(1764) \\
\text { 乾隆41 }(1776) \\
\text { 乾隆54 }(1789) \\
\text { 純祖元 }(1801) \\
\text { 嘉慶10 }(1805) \\
\text { 道光 } 4(1824) \\
\text { 道光 } 12(1832) \\
\text { 純祖 } 34(1834)\end{array}$ & 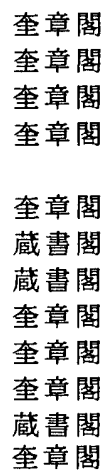 \\
\hline $\begin{aligned} * 1 & \text { は『華城户 } \\
* 2 & \text { は『㘴章屋 }\end{aligned}$ & 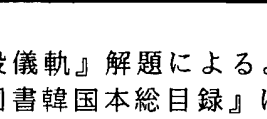 & \\
\hline
\end{tabular}

表 $4 \quad 17 \cdot 18$ 世紀半ばまでの都監の椿成

\begin{tabular}{|c|c|c|c|c|c|c|c|c|}
\hline 昌 慶 宮 & 徳 & 萬寿 殿 I & 萬 寿 殿 II & 永寧殿 $I$ & 永寧殿 II & 南 別 & 宗 & 真 \\
\hline $\begin{array}{ll}\text { 堂 } & \text { 上 } 7 \\
& \\
\text { 都 } & \text { 庁 } 2 \\
\text { 郎 } & \text { 庁 } 6 \\
\text { 監役官 } 6\end{array}$ & $\begin{array}{llll}\text { 都 } & \text { 提 } & \text { 調 } & 1 \\
\text { 提 } & & \text { 調 } & 5 \\
\text { 都 } & & \text { 庁 } & 2 \\
\text { 郎 } & & \text { 庁 } & 6 \\
\text { 監 } & \text { 造 } & \text { 官 } 14\end{array}$ & 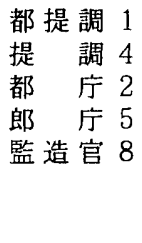 & 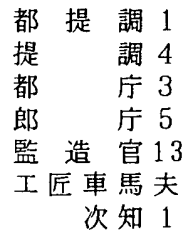 & 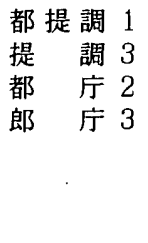 & $\begin{array}{llll}\text { 都 } & \text { 提 } & \text { 調 } & 1 \\
\text { 提 } & & \text { 調 } & 5 \\
\text { 都 } & & \text { 宁 } & 4 \\
\text { 郎 } & & \text { 庁 } & 3 \\
\text { 監 } & \text { 造 } & \text { 官 } 4\end{array}$ & 堂 上 3 & 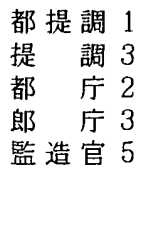 & $\begin{array}{llll}\text { 都 } & \text { 提 } & \text { 調 } & 1 \\
\text { 提 } & & \text { 調 } & 3 \\
\text { 都 } & & \text { 庁 } & 2 \\
\text { 郎 } & & \text { 庁 } & 3 \\
\text { 監 } & \text { 造 } & \text { 官 } & 4\end{array}$ \\
\hline 貝役 & $\begin{array}{l}\text { 領役 部 将 } 32 \\
\text { 員 役 }\end{array}$ & & $\begin{array}{l}\text { 領 役 部 将 } 60 \\
\text { 員 役 }\end{array}$ & & 員役 & 員役 & 員役 & $\begin{array}{l}\text { 貝 役 } \\
\text { (領役部将) } \\
\text { (看役人) }\end{array}$ \\
\hline
\end{tabular}

（）内は「座目」に記されていない者 
提調は、1人を除いてすべて正二品以上であり、都提調につづく 高位である。また、延 31 人の提調のうち27人が六曹の長である判書 であり、提調には六曹の判書クラスが配されることが基本であった と考えられる。

堂上は、交代して加入した 1 人を除いて他は正二品以上の者であ る。前述のように「堂上」は正三品以上のものをさす一般的な呼称 と考えられるが、ここでみられる堂上は品階および人数から提調と 同様の者であるとみられる。

提調・堂上の所属は表 5 に示すようになり、各「都監」には戸曹 の判書、参判がおり、「真殿重修」と交代後の「宗廟改修」を除い てはエ曹の判書が含まれている。交代する場合にも、表のように所 属が同じ者に交代する場合が多く、これは建築工事を掌る工曹と賦 役に関係する戸曹との協力が建築工事という性格上、特に必要であ ったためと考えられる。また、「昌慶宮修理」や「昌徳宮修理」な どの宮殿に関する工事では兵曹、「永寧殿修改」「南別殿重建」 「宗㾰改修」の工事には礼曹の判書、参判が必ず提調となっている か、これも宮殿の管理に関係する兵曹、祭享を掌る礼曹との協力が 建物の性格上、必要であったためと考えられる。

表 5 提調・堂上の所瓜（矢印は交代による変化）

\begin{tabular}{|c|c|c|c|c|c|c|c|c|c|}
\hline & 昌罳宮 & 昌徳宮 & 苚寿殿 I & 苗寿殿II & 永㸘殿 I & 永㸘殿II & 南放殿 & 宗 廟 & 真殿 \\
\hline 工曹 & 1 & 1 & 1 & 1 & 1 & 1 & 1 & $1 \rightarrow 0 \rightarrow 0$ & 0 \\
\hline 戸曹 & $1 \rightarrow 1$ & 1 & 1 & 1 & 1 & 1 & 1 & 1 & 1 \\
\hline 兵曹 & 1 & $2 \rightarrow 2$ & 1 & 1 & 0 & 1 & 0 & 0 & $0 \rightarrow 1$ \\
\hline 礼曹 & 0 & 0 & 0 & 0 & 1 & 1 & $1 \rightarrow 1 \rightarrow 1$ & 1 & $1 \rightarrow 0$ \\
\hline 他 & 4 & 1 & 1 & 1 & 0 & 1 & 0 & $0 \rightarrow 1 \rightarrow 1$ & 1 \\
\hline
\end{tabular}

（2）都庁・郎庁 監造官

都庁は「南別殿重建」以外の 8 つの「都監」でみられ、人数は再 開後の「萬寿殿修理」で途中から増員して 3 人、同じく再開後の 「永寧殿修改」で途中から 4 人となるほかは 2 人であり、 2 人が基 本であったと考えられる。また、都庁の品階は正三品〜従六品であ るが、なかでも三・四品の者が多い。

郎庁は各「都監」に3〜6人ずつおり、品階は五・六品が多い。 また、交代者を除いた延 37 人の郎庁のうち 32 人が六曹の官吏である 正郎・佐郎である。そして、表 6 のように、提調・堂上の場合と同 しようにエ曹・戸曹の正郎や佐郎を含み、さらに宮殿の工事では兵 曹、祖廟関係の工事では礼曹の正郎や佐郎を含むという傾向がみら れる。

都庁・郎庁に関しては各「儀軌」に記載の事目（公事をすすめる に際して定めた規則）に

一郎廳八貝内弘文館應教南老星禮賓寺正李一相都铒稱號其餘六 員分掌五所董役為白齊

というような項があり ${ }^{20)}$ 、郎庁のなかから（おそらくは品階の高い） 2 名が都庁を称する者と定められたことがわかる。

上記の事目の「所」は「都監」の工事を建物ことに、または工事 内容によって分けたものである ${ }^{21)}$ 。郎庁はこの各々の「所」に 1 〜2人ずつ配され工事を管理したことがわかる。なお「爐冶所」や 「別工作」には郎庁がいないことが多い。
郎庁は監造官とともに木手を伴って材木の選定に行ったりエ事に 必要な物資を担当するという記事が「儀軌」にみられ の直接的な関与がみられる。

監造官は、停罷前の「永寧殿修改」と「南別殿重建」を除いた 7 つの「都監」で各「所」に1〜4人ずつ配されている。品階は正六 品〜従九品であり、工曹のうち土木・建築を管掌する綪工監の者が 必ず含まれている。特に各「儀軌」の事目には「別工作」の監造官 を綁工監から選ふと定められ ${ }^{23)}$ 、「別工作」「曥冶所」の監造官 は必ず繥工監の者である。また、監造官がいない「南別殿重建」で も「別工作」の郎庁には、郎庁としては品階が低い繯工監の官吏で ある監役官（従九品）が配されている。

監造官も郎庁とともに木手を連れて材木を選びに行ったり ${ }^{24)} 、$ 宿直をする ${ }^{25)}$ という記事が儀軌」のなかにみえ、郎庁とともに 直接的に工事に関与していたものと考えられる。

表 6 郎廳の所后（矢印は交代による変化）

\begin{tabular}{|c|c|c|c|c|c|c|c|c|c|}
\hline & 昌慶宮 & 昌徳宮 & 萬寿殿 I & 萬寿殿II & 永寧殿 I & 永㸘殿II & 南別澱 & 宗朝 & 真殿 \\
\hline 工曹 & 2 & $2 \rightarrow 1$ & 2 & $3 \rightarrow 2$ & 1 & $1 \rightarrow 1$ & 2 & 1 & 1 \\
\hline 戸曹 & 1 & 1 & 2 & 1 & 1 & $1 \rightarrow 0$ & $1 \rightarrow 1$ & $1 \rightarrow 1$ & $1 \rightarrow 1$ \\
\hline 兵曹 & $1 \rightarrow 1$ & 1 & 1 & $1 \rightarrow 1 \rightarrow 0$ & 0 & 0 & 0 & $0 \rightarrow 1$ & 0 \\
\hline 礼曹 & 0 & $1 \rightarrow 0$ & 0 & 0 & 1 & $1 \rightarrow 0$ & $1 \rightarrow 1$ & $1 \rightarrow 0$ & $1 \rightarrow 0$ \\
\hline 他 & $1 \rightarrow 1$ & $1 \rightarrow 3$ & 0 & $0 \rightarrow 1 \rightarrow 2$ & 0 & $0 \rightarrow 2$ & 0 & 0 & 0 \\
\hline
\end{tabular}

（3）その他

以上のほか「都監」には「員役」として書吏・算員等がいる。こ れらは字義より記録や経理等の事務的な仕事に従事する者と考えら れる。また「萬寿殿修理」では監造官につづいて「諸色工匠及車馬 夫次知」として、漢城府参軍（正七品）の官職をもつ者が記されて いる。「萬寿殿」では漢城府が工匠の供給をまかされている点から、 工匠・車馬夫の供給・管理の任にあたったものと推定できる。

\section{5. 李朝後期、18 世紀半ば以降の都監の棈成}

18世紀半ば以降の14の「都監」（「垂恩廟」では、「営建」と 「移建」の二つの「都監」が記録されている）の構成を示したのが 表 7 である。この表をみると、18世紀半ば以前のように都提調、提 調、都庁、郎庁、監造官という構成となる例がほとんとみられなく なり、主な構成員が $2 \sim 5$ 名程度の小規模なものが一般的となる。

\section{（1）18世紀半ば以降の一般的な桡成}

「文糦㾰営建」「華城城役」「顕思宮営建」「永寧殿增修」「南

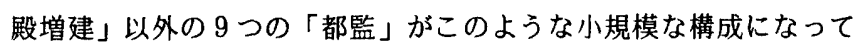
いる。堂上、提調または監董堂上と称される 1 名がもっとも品階の 高い者で、工事を統括すると考えられる。「景慕宮改建」以外はい ずれも戸曹判書であり、「景慕宮改建」では戸曹参判が堂上となっ ている。この下には郎庁がおかれ、「仁政殿営建」では 2 名、その 他では 1 名である。いずれも、戸曹の正郎・佐郎である。また、 「竞昭廟営建」「垂恩廟営建」「景慕宮改建」「仁政殿営建」では 縉工監の者が監役官として配されているが、その他の工事では監役 官はみられない。 
これらのエ事では「垂恩廟営建」「景慕宮改建」を除いて、18世 紀半ば以前にはみられなかった看役や牌将という者が、何名かずつ 配されている。看役や牌将の、はっきりとした役割は不明であるが、 「看役」とは役事の世話をすること、「牌将」とは工匠を率いる者

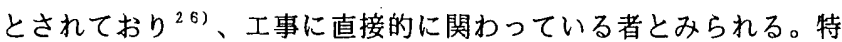
に、牌将は金東旭博土の指摘にもあるように、他の工事で木手とし

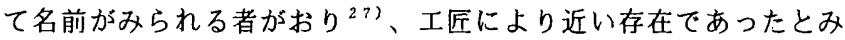
られる。これらの者は「前…」とあったり、「出身」「閉良」とあ る者が多い。すなわち、看役や牌将の多くは、現役の官僚ではなく、 官職を退いた者や宫職に就いていない者であり、18世紀半ば以前の 官僚を中心とした組織に代わって、彼らが工事の直接的な監督を行 っていたと考えられる。

このように、議政府の議政クラスを頂点として多くの高い品階を 持つ者によって構成された18世紀半ば以前の工事に比へ、18世紀半 ば以降の「都監」では高い品階の者が減り、もっとも少ない例では、 提調と郎庁の二人だとなっている。また、この二人は、いずれも 賦役に関係するとみられる戸曹に属し、工事に関わる仕事のうち賦 役の管理が彼らの仕事の中心であったことをうかがわせる。

\section{（2）規模が大きな「都監」の檑成}

「都監」の構成員が多い、比較的規模が大きな「都監」には、 「文禮廟営建」「顕思宮営建」「永寧殿修改」と「華城城役」があ る。

このうち、「華城城役」は、水原城築城という李朝後期の大工事 であり、多くの構成員が配されている。筆頭は捴理大臣で正二品の 領中枢府事、続いて監董堂上、都庁、策応都庁が各 1 名ずつ配され ている。監董堂上は「水原府留守」、策応都庁は「水原府判官」で いずれも水原府の関係者であり、賦役に関係していたとみられる。 この下に多くの別監董・監董・別看役 - 看役 - 京監官 ·府監官 · 京 牌将・府牌将がいるが、いずれもほとんどが前職あるいは䦥良や嘉 善、折衝という官位のない者たちである。

このエ事では、表 7 にみように、工事の規模は大きいが、実質 的な「都監」の組織としては捴理大臣、監董堂上、都庁、策応都庁 の 4 名とみられ、前述の18世紀半ば以降の一般的な「都監」の構成 と似た構成といえる。
次に、「文禧廟営建」と「顕思宮営建」では、全体を統括すると みられる監董大臣は、「文禧廟営建」では正一品の議政府左議政で あり、「顕思宮営建」では正二品の行判中枢府事が任命されている。 その下に六曹の判書クラスの者 3 名が、「文禧廟営建」では堂上、

「顕思宮営建」では提調として配されている。この下には、さらに 郎庁がおり、「文禮廟営建」ではそのうち 1 名が都庁とされている。 郎庁および都庁はいずれも礼曹・戸曹・工曹の正郎である。

このような構成は上記の18世紀半ば以前の「都監」と似ているが、 一方で、これらのエ事では、18世紀半ばまでにみられた工事区分の 「所」がなく、郎庁も「所」に配されることはなく、監造官も縉工 監の者が 1 名いるだけである。また、「文禧廟営建」では 5 名の看 役牌将、「顕思宮営建」でも看役牌将、運石牌将、浮石牌将、外墙 看役牌将など、牌将が置かれている。このような牌将は、上記のこ

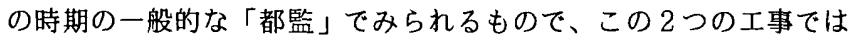
郎庁と監造官が「所」に配されず工事との直接的な関係が薄れ、代 わって牌将が置かれている点で、この時期の一般的な「都監」と共 通する点も多い。

これに対し、「永寧殿增修」と「南殿增建」には18世紀半ば以前 と同じく都提調、提調、都庁、郎庁、監造官で構成され、19世紀の 「都監」としては特異な構成となっている。都提調は、「永寧殿増 修」では18世紀半ば以前の「都監」とは少し異なり、正二品の「行 判中枢府事」であるが、「南殿増建」では正一品の「議政府領議 政」である。提調にはそれそれ礼曹、戸曹、工曹の判書があてられ、 都庁は二名である。また、郎庁もそれそれ戸曹、礼曹、工曹の正郎 の三名でそれそれ「所」に配されており、監造官も各「所」に配さ れる。一方、この工事でも何名かの「牌将」がみられ、この点では この時期の他の「都監」と同様である。

「文䄈㾰営建」「顕思宮営建」「永寧殿增修」「南殿増建」の 4 つの「都監」で、このように18世紀半ば以前と似た比較的規模が大 きい「都監」が構成された理由については明確ではない。しかし、 これらの「都監」では、定礎や立柱・上梁などの建築工事に係わる 儀式のほかにさまざまな祭享の儀式が行われている ${ }^{28)}$ 。したがっ て、賦役を管理する戸曹だけでなく、祭享の儀式を掌る礼曹との協 力も「都監」に必要であり、このような構成となったのではないか と考えられる。

表 718 世紀半ば以降の「都監」の構成

\begin{tabular}{|c|c|c|c|c|c|c|c|c|c|c|c|c|c|}
\hline 耪 昭 廟 & 垂恩廟営建 & 垂恩廟移建 & 景 慕 宮 & 文 禮 廟 & 華城城役 & 仁政 殿 & 思 宮 & 昌慶宮 & 昌 德 宮 & 西 & 永 寧 殿 & 仁 政 殿 & 南 \\
\hline $\begin{array}{ll}\text { 堂 } & \text { 上 } 1 \\
& \\
\text { 郎 } & \text { 庁 } 1 \\
\text { 監役宫 } 1\end{array}$ & $\begin{array}{l}\text { 堂 上 } 1 \\
\text { 郎 庁 } 1 \\
\text { 監役官 } 1\end{array}$ & $\begin{array}{l}\text { 堂 } 上 1 \\
\text { 郎 庁 } 1 \\
\text { 監役官 } 1\end{array}$ & $\mid \begin{array}{ll}\text { 堂 } & \text { 上 } 1 \\
& \\
\text { 郎 } & \text { 庁 } 1 \\
\text { 監造官 } 1 \\
\text { 築墻都庁 }\end{array}$ & $\mid \begin{array}{lr}\text { 監董大臣 } 1 \\
\text { 堂 } & \text { 上3 } \\
\text { 都 } & \text { 广丁 } 1 \\
\text { 郎 } & \text { 庁 } 2 \\
\text { 監 } & \text { 造 } \\
\text { 官 } 1\end{array}$ & $\begin{array}{l}\text { 捴理大臣 } 1 \\
\text { 監董堂上 } 1 \\
\text { 都 庁 } 1 \\
\text { 策応都庁 } 1\end{array}$ & $\mid \begin{array}{l}\text { 提 } \\
\text { 調 } 1 \\
\text { 郎 } \text { 庁 } 2 \\
\text { 別工作 } 2\end{array}$ & $\mid \begin{array}{ll}\text { 監董大臣 } 1 \\
\text { 提 } & \text { 調 } 3 \\
& \\
\text { 郎 } & \text { 庁 } 3 \\
\text { 監 造 } & \text { 官 } 1\end{array}$ & 提調 1 & 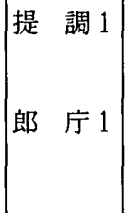 & $\mid \begin{array}{ll}\text { 提 } & \text { 調 } 1 \\
\text { 郎 庁 } 1\end{array}$ & 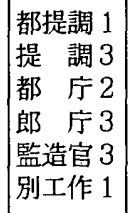 & $\mid \begin{array}{cc}\text { 監董堂上 } \\
\end{array}$ & $\begin{array}{ll}\text { 都提調 } 1 \\
\text { 提 } & \text { 調 } 3 \\
\text { 都 } & \text { 庁 } 2 \\
\text { 郎 } & \text { 庁 } 3 \\
\text { 監造官 } 3 \\
\text { 別工作 } 1\end{array}$ \\
\hline $\begin{array}{c}\text { 貝 役 } \\
\text { 領役部将 }\end{array}$ & $\begin{array}{c}\text { 員 役 } \\
\text { 領役部将 } \\
\text { 捕盗軍官 } \\
\text { 捕盗軍士 }\end{array}$ & $\begin{array}{c}\text { 貝 役 } \\
\text { 別 看 役 } \\
\text { 領役部将 } \\
\text { 相 地 官 } \\
\text { 捕盗軍士 }\end{array}$ & $\mid \begin{array}{cc}\text { 員 } & \text { 役 } \\
(\text { 看 } & \text { 役 }) \\
(\text { 別看役 }) \\
\text { (茼室 } \\
\text { 看役) } \\
(\text { 領役 } \\
\text { 部将) }\end{array}$ & \begin{tabular}{|l} 
別 看 役 \\
看役牌将 \\
雑物看役 \\
侍 令 \\
員 役 \\
(運石牌将) \\
\end{tabular} & 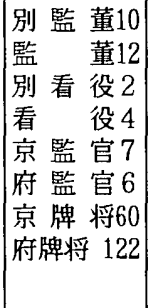 & $\begin{array}{l}\text { 別 看 役 } \\
\text { 領役牌将 } \\
\text { (看 役) } \\
\text { (領役 } \\
\text { 捕校 }) \\
(\text { 守直 } \\
\text { 捕校 })\end{array}$ & $\begin{array}{l}\text { 別 監 役 } \\
\text { 看役牌将 } \\
\text { (浮石牌将) } \\
\text { (木手牌将) } \\
\text { (外墻看役 } \\
\text { 牌将) }\end{array}$ & $\begin{array}{l}\text { 別看役 } \\
\text { 営建 } \\
\text { 都牌将 } \\
\text { 各所 } \\
\text { 牌将 } \\
\text { 員 役 }\end{array}$ & 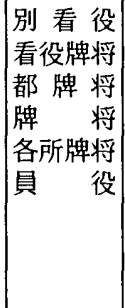 & $\begin{array}{c}\text { 別 看 役 } \\
\text { 各所牌将 } \\
\text { 員 役 } \\
\end{array}$ & $\begin{array}{c}\text { 員 役 } \\
\text { (別看役) } \\
\text { (看役 } \\
\text { 都牌将) } \\
\text { (牌 将) } \\
\text { (捕校兼 } \\
\text { 牌将) } \\
\text { (冶所 } \\
\text { 牌将) }\end{array}$ & 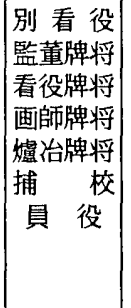 & $\begin{array}{c}\text { 員 役 } \\
\text { (別看役) } \\
\text { (看役 } \\
\text { 牌将) } \\
\\
\end{array}$ \\
\hline
\end{tabular}

（）内は、「座目」に記されていない者 
6. 結

『李朝実録』やソウル南大門の畦書（上梁文）から李朝前期の建 築工事の組織をみると、李朝最初期の「都監」では、判事、副判事、 使、副使、判官、録事という構成となっている。このような「都 監」の構成は、高麗の都監の構成を受け継いだものとみられる。 その後、15世紀にはいると徐々に李朝後期の「都監」でみられる 提調や監役官が置かれるようになり、さらに郎庁がみられるように なる。提調や郎庁は、それそれ賦役を担当する戸曹や工事を管轄す るエ曹の者、さらに郎庁には建築工事を担当する䋹工監の官吏も含 まれており、李朝後期の「都監」により近い構成へと変化する。

李朝の社会体制は、当初、高麗の体制を受け継いたか、『経国大 典』が成宗 2 年(1470)に施行されたことによって、李朝の体制が確 立されたとされる291。「都監」の組織もまさにこれと対応した変 化をしている。すなわち、高麗の制度を受け継いだ李朝最初期から 15・16世紀を通じて、李朝の構成へと変化している。

李朝後期になると、「都監」の構成は『増補文献備考』にみられ るような都提調を筆頭とした構成がみられるようになる。18世紀半 ば以前には、都提調は 1 名で正一品、主として議政府の議政である。 この下に提調が数人おり、正二品以上で六曹の判書であることが多 い。提調には工曹・戸曹、建物の性格によって兵曹・礼曹の判書や 佐郎が含まれる。提調の下の都庁は、三・四品程度の者 2 名で郎庁 のなかから指名される。郎庁は各「所」に1・2 名配され、五・六 品程度、六曹の正郎・佐郎が多く、提調の場合と似た傾向がみられ る。監造官も各「所」に配され人数は 1 ～4人ずつであり、品階は 六〜九品である。工曹のうち土木・建築を管掌する繕工監の官吏が 多い。

18世紀半ば以降になると、中央の官僚が「都監」の組織に加わる 割合が隇っている。18世紀半ば以降の一般的な建築工事では、賦役 に関わる戸曹の判書と正郎が「都監」の組織に加わるだけで、18世 紀半ば以前のような大規模な工事組織は作られなくなる。代わりに、 官職のない者たちが看役や牌将として工事組織に組み込まれている。

注

1）杉山信三「麗末鮮初に見る造営の監董者について」（『朝鮮建築史研究報 告』第三冊、昭和25年、私家版) および「麗末鮮初代の造営活動とその監董 者について」（朝鲜学報 2、昭和26年10月）

2）申榮䵢『韓屋과 ユ 歴史』(1975年、에밀레美術館）および『韓国古建築 断章 上』(1975年、東山文化社)

金東旭「朝鮮時代 造営組織研究 I III」（大韓建築学会誌 巻27-112、

113、115号、1983年 6、8、12月)

3）金東旭「大朴より見た李朝時代の建築工匠」（日本建築学会論文報告集

327、昭和58年 5月）およひ『韓国建築工匠史研究』（1993年、技文堂）

4) 朴彦坤. 李王基「朝鮮王朝의 営造 職制에 관한 研究」(大韓 建築学会誌 巻24-97、1980年12月)

5) 洪錫珠·朴彦坤「光海君 代의 宮閵 営建에 관한 연구」(建築 歴史研究 第 8 巻 4 号、1999年12月)

6) 增補文献備考 巻二百二十七 職官考十四 都監

なお、ここには、册礼都監以下の各種都監についても記されているか、この 中に営建都監の項はない。

7) 英祖46年（1770）に王命によって『東国文献備考』が編算され、その後正 祖 6 年 (1782) に改訂され『增補東国文献備考』が編篹された。これをもと に高宗代になってさらに改訂され1908年に刊行されたのが增補文献備考』 である。

8）太祖実録 巻九 五年丙子正月戊辰条

9）高麗史 志 巻三十一 百官二 諸司都監各色条

10）高麗史 列伝 巻二 后妃二 魯国大長公主条

11）建筑工事と関連して、監督者が「提調」と呼ばれる例は、すでに太祖 4 年

(1395)の大廟の工事で「董役提調官」と呼ばれる例がみられる。

12）世宗実録 巻十四 三年十二月己亥条
13）端宗実録 巻四 即位年十二月己亥条

14）李弘稙 編『새国史辞典』（1978年、大栄文化社）

15) 서울南大門修理報告書作成委員会 編『서울南大門修理報告書』(서울特別 市教育委員会、1966年)

16）二つの墨茟の内容はほぼ同しだか、棟木のものでは第 1 段に判事として 「嘉靖大夫中枢院使崔有慶」とあるのに続いて「正憲大夫全羅道都観察黜陟 李茂」と「推忠翊載開国功臣資害大夫完山府尹孫興宗」とあるか、、上層長舌 のものでは後の二人は畦書の最後に記されている。

17）世宗実録 巻百十七 二十九年八月己丑条

18）成宗実録 巻九十九年三月壬午条

19）增補文献備考 巻二百二十七 職官考十四 都監

20）昌徳宮修理都監嶬軌 丁亥六月十五日 都監事目

21）拙稿「朝鮮、李朝における建築工事区分と建築工匠について」（日本建築 学会計画系論文集 491、1997年 1月) 参照。

22）昌徳宮萬壽殿修理都監儀軌 呙申八月初九日 …昨日郎鹿監造官分往江上擇執材木之際欲带木手而僅得二名… 昌慶宮修理都監儀軌 四月初一日事目單子

一郎麻五員分三房察任為白乎矣米布雜物則戸曹郎廳次知軍匠則兵曹漢城 府郎廳材木鉄炭等則工曹綪工監郎鹿分掌為白齊

23）たとえば昌徳宮修理都監儀軌 丁亥六月十五日都監事目に、 一別工作監造官乙良令緗工監擇定為白齊

24) 注22

25）永學殿修改都監儀軌一所、手本秩丁未三月初三日 一本所今月初一日始役乙仍子監造官一員直宿之意 啓下為有等以今日為始每日燈油七夕式㕵炬一俩式上下進排事捀甘為只 為堂上手決内依

26）李熙昇 編『国語大辞典』（1961年、民衆書林）

27）金東旭 前掲書 214 ペーシ

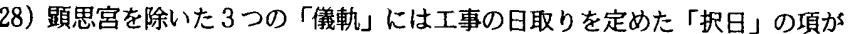
あり、そこに、建築工事に関する「定礎」や「上梁」のほかに次のような儀 式の日取りか記されている。

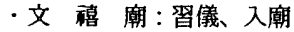

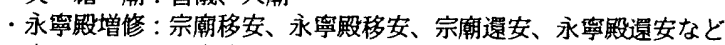

・南殿 : 各室移安、純祖大王御真権安斉殿、各室還安など

29）韓淤欣（平木實 訳）『韓国通史』（昭和51年、学生社）

（2001年 1 月 5 日原稿受理，2001年 3 月 15 日採用決定） 